ognition of uranium provinces, 305-335. Vienna: International Atomic Energy Agency.

Steenfelt, A. \& Kunzendorf, H. 1979: Geochemical methods in uranium exploration in northern East Greenland. In Watterson, J. R. \& Theobald, P. K. (ed.) Geochemical exploration 1978, 429-442. Rexdale, Ontario: Association of Exploration Geochemists.

Taylor, S. R. \& McLennan, S. M. 1985: The continental crust: its composition and evolution, 312 pp. Oxford: Blackwell Scientific Publications.

Thomassen, B. 1989: Evaluation of the niobium-tantalum po- tential of the Motzfeldt Centre, South Greenland. Rapp. Grønlands geol. Unders. 145, 66-73.

Tukiainen, T. 1988: Niobium-tantalum mineralisation in the Motzfeldt Centre of the Igaliko Nepheline Syenite Complex, South Greenland. In Boissonnas, J. \& Omenetto, P. (ed.) Mineral deposits within the European Community, 230-246. Berlin: Springer Verlag.

A. S. \& T. T., Geological Survey of Greenland, Copenhagen.

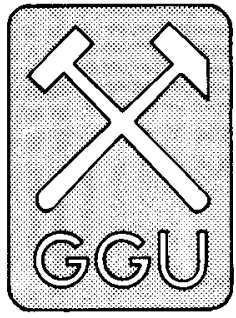

\section{Registration of kimberlites and other potentially diamond-bearing rocks in Greenland}

Lotte Melchior Larsen
Kimberlites are potentially diamondiferous rocks. They have been found at a number of localities in Greenland (Fig. 1), notably in the Holsteinsborg-Sarfartôq region and south of Frederikshåb (Andrews \& Emeleus, 1971, 1975, 1976; Larsen, 1980; Scott, 1977, 1979, 1981; Thy et al., 1987). Prospecting for diamonds and kimberlites was carried out by several mining companies in West Greenland in the years 1970-1988.

In recent years it has been realised that other rocks than kimberlites may carry diamonds. Some lamproites are now known to carry significant amounts of diamonds (Scott-Smith \& Skinner, 1984; review by Bergman, 1987), and also ultramafic lamprophyres sometimes contain a few diamonds (Rock, 1986; Hamilton \& Rock, 1990). Such rocks are also known from various localities in Greenland.

The potentially diamondiferous rocks kimberlite, lamproite and ultramafic lamprophyre are all of very deep-seated origin, hence the diamonds which are only stable at more than $150 \mathrm{~km}$ depth. They are all volatilerich and strongly potassic, and distinction between the three groups involves a complex set of mineralogical and geochemical criteria. They occur mostly as thin dykes and sometimes as narrow volcanic pipes. The rocks weather easily and tend to be covered by soil and vegetation. Because of this they are very elusive rocks, and it is difficult to establish a true picture of their distribution in a region.
Some information about occurrences of kimberlites and related rocks in Greenland is published, as cited above. However, much unpublished information resides in the Geological Survey of Greenland (GGU) in a variety of forms ranging from Ph.D. and other theses through internal reports from scientists and mining companies to scattered field notes and samples from many mapping teams. All mining company reports relevant in this connection are now available to the public. In order to provide interested parties with more easy access to this very heterogeneous information source, a computer-based registration system has been established at GGU, covering all the currently known occurrences of kimberlite, lamproite and ultramafic lamprophyre.

\section{Registration}

Each known locality has been given a number. The first part of the number is that of the Kort- og Matrikelstyrelsen (KMS, formerly Geodetic Institute) 1:250 000 topographical map sheet on which the locality is situated, while the second part is a consecutive number. This allows the number of localities within a given map sheet to increase with time as necessary. For each locality existing information is compiled in a standard form, as shown by the example in Table 1 . In some instances the information available amounts only to a locality and 


\section{Table 1. Example of detailed information registered for a locality}

Locality no:

$65 \mathrm{~V} 1.2$

Coordinates

65.392

$-52.400$

Place name:

Rock type:

Field description:

Primary locality:

Samples:

Alanguarssuk, Søndre Isortoq south coast

\section{Kimberlite}

Dyke 0.6-2 m thick, orientation 46/90, coast parallel. Exposed over c. $150 \mathrm{~m}$.

Rock analyses:

Mineral analyses;

Modal analyses:

Rb-Sr data:

K-Ar data:

Comments:

References:

Goff (1973)

'Coordinates': Latitude and longitude in decimal degrees. The minus sign indicates western longitude.

-Primary locality: Original locality number from field notes or thesis given for ease of access to the original source.

a reference, while at the other extreme a whole thesis may be written over one locality.

At present the total number of localities registered is around 500 . The detailed information about localities, as shown in Table 1, will be available as computer printouts on request. A summary list has been compiled giving only number, coordinates and rock type, as shown by the example in Table 2 . This list, together with distribution maps and descriptions of the main rock groups, will be available as Open File Series 91/2.

Information about the kimberlite localities is planned to be included in the Greenland Mineralisation Data Bank, GREENMIN.

\section{Distribution}

The localities are very unevenly distributed, depending on the fact that the rocks often occur in swarms, and on the degree of detail with which an area has been investigated. Figure 1 shows the location of the main swarms. The distribution of localities on the 1:250 000 topographic map sheets in West Greenland is shown in Table 3 . Occurrences of the rocks in question are extremely scarce elsewhere in Greenland; they are known only from the Caledonian ultramafic, ultrapotassic Batbjerg complex from Kangerdlugssuaq, East Green-

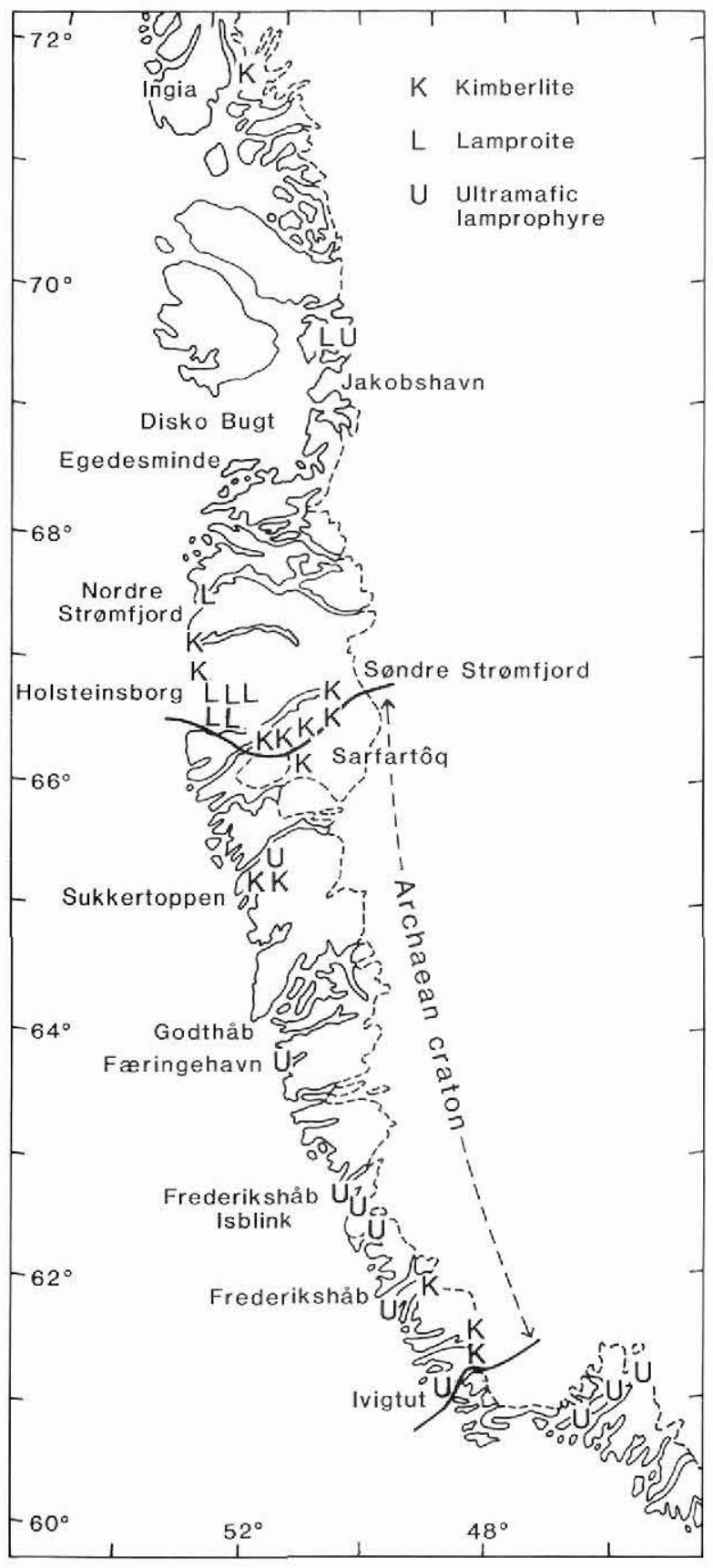

Fig. 1. Distribution of kimberlites, lamproites and ultramafic lamprophyres in western Greenland.

land, and as two ultramafic lamprophyre dykes of Tertiary age from Scoresby Sund, East Greenland. (Occurrences of carbonatites and more salic lamprophyres are not included in the compilation.) The large number of kimberlite occurrences registered on map sheet $66 \mathrm{~V} 2$ Søndre Strømfjord is due to a combination of the two facts mentioned above: there is a large kimberlite 
Table 2. Summary list of localities with kimberlite and related rocks in the Sukkertoppen district (map sheets 65V1 and 65V2)

\begin{tabular}{|c|c|c|c|}
\hline Loc. no. & Lat. (N) & Long. (W) & Rock type \\
\hline $65 \mathrm{~V} 11$ & 65.4588 & -52.7078 & Mica-rich ultramafic lamprophyre \\
\hline $65 \mathrm{~V} 12$ & 65.392 & -52.400 & Kimberlite \\
\hline $65 \mathrm{~V} 13$ & 65.35833 & -51.8843 & Kimberlite \\
\hline $65 \mathrm{~V} 14$ & 65.30751 & -52.3008 & Kimberlite \\
\hline $65 \mathrm{~V} 15$ & 65.303 & -52.267 & Kimberlite, alkali basalt \\
\hline $65 \mathrm{~V} 16$ & 65.26129 & -51.7824 & Kimberlite \\
\hline $65 \mathrm{~V} 17$ & 65.22633 & -51.9873 & Kimberlite \\
\hline $65 \mathrm{~V} 18$ & 65.21247 & -52.1980 & Kimberlite \\
\hline $65 \mathrm{~V} 19$ & 65.18161 & -52.2965 & Kimberlite \\
\hline $65 \mathrm{~V} 110$ & 65.08441 & -52.1794 & Kimberlite \\
\hline $65 \mathrm{~V} 111$ & 65.08306 & -52.0328 & Kimberlite \\
\hline $65 \mathrm{~V} 112$ & 65.45 & -52.80 & Carbonatitic lamprophyre (kimberlite?) \\
\hline $65 \mathrm{~V} 21$ & 65.40225 & -51.7013 & Micaceous lamprophyre \\
\hline $65 \mathrm{~V} 22$ & 65.37000 & -51.5518 & Micaceous lamprophyre \\
\hline $65 \mathrm{~V} 23$ & 65.37560 & -51.5381 & Micaceous lamprophyre \\
\hline $65 \mathrm{~V} 2$ & 65.38238 & -51.5185 & Micaceous lamprophyre \\
\hline $65 \mathrm{~V} 25$ & 65.32469 & -51.6905 & Kimberlite \\
\hline $65 \mathrm{~V} 2$ & 65.30165 & -51.6460 & Kimberlite \\
\hline $65 \mathrm{~V} 27$ & 65.29249 & -51.7114 & Kimberlite \\
\hline $65 \mathrm{~V} 28$ & 65.19748 & -51.5421 & Kimberlite \\
\hline $65 \mathrm{~V} 29$ & 65.19843 & -51.5286 & Kimberlite \\
\hline $65 \vee 210$ & 65.19373 & -51.5198 & Kimberlite \\
\hline $65 \mathrm{~V} 211$ & 65.08149 & -51.7148 & Kimberlite \\
\hline $65 \mathrm{~V} 212$ & 65.37806 & -51.5319 & Micaceous lamprophyre \\
\hline
\end{tabular}

Coordinates (latitude and longitude) are given in decimal degrees. The minus sign indicates western longitude.

swarm, and the rocks have been systematically searched for (Larsen, 1980). The lack of reported occurrences from the map sheets $67 \mathrm{~V} 2,68 \mathrm{~V} 1$ and $68 \mathrm{~V} 2$, covering eastern Nordre Strømfjord and the Egedesminde and Christianshåb districts, may be due more to a lack of detailed work than to an absence of occurrences - this is not known at present. On the other hand the absence of reported occurrences in the very well investigated Godthåbsfjord region (map sheets $64 \mathrm{~V} 1$ and $64 \mathrm{~V} 2$ ) must reflect a real absence of occurrences there.

\section{Kimberlites}

Kimberlites occur in three major 'swarms' in West Greenland: (1) In the Holsteinsborg-Sarfartôq region at the northern margin of the Archaean craton (map sheets $66 \mathrm{~V} 1,66 \mathrm{~V} 2,67 \mathrm{~V} 1$ ); they are c. 600 million years old. (2) In the Sukkertoppen region in the central part of the Archaean craton (map sheets $65 \mathrm{~V} 1,65 \mathrm{~V} 2$ ); these are also c. 600 million years old. (3) In the Pyramidefjeld-Midternæs-Nigerdlikasik region at the southern margin of the Archaean craton (map sheets 61V1, $62 \mathrm{~V} 1$ ); these are c. 220 million years old. References are cited above in the introduction. Kimberlite dykes have also been reported from Íngia, at $72^{\circ} \mathrm{N}$ (Smith, 1981), but little is known about this occurrence.

A few microdiamonds were found in bulk rock samples from the Pyramidefjeld and Midternæs kimberlites (Geisler, 1972), and two microdiamonds were recovered from large stream sediment samples from the Sarfartôq region (Brunet, 1974, 1976). The Sukkertoppen kimberlites have not been investigated for diamonds.

\section{Lamproites}

Lamproites were intruded into shear zones in the Proterozoic continental collision zone north of the Archaean craton around 1230 million years ago (Scott, 1979, 1981; Thy et al., 1987; map sheets 66V1, 67V1); they are mostly leucite lamproites, a type which normally does not carry diamonds. A small lamproite pipe 
Table 3. Number of localities with kimberlite, lamproite and ultramafic lamprophyre in western Greenland

\begin{tabular}{|c|c|c|c|c|}
\hline $\begin{array}{l}\text { KMS } \\
1: 250000 \text { map sheet }\end{array}$ & kimberlite & lamproite & $\begin{array}{c}\text { ultramafic } \\
\text { lamprophyre }\end{array}$ & tota \\
\hline $60 \mathrm{~V} 1$ Julianehăb & & & 12 & 12 \\
\hline 60V2 Nanortalik & & & 4 & 4 \\
\hline $61 \mathrm{~V} 1$ Ivigtut & 26 & & 40 & 66 \\
\hline 61V3 Narssarssuaq & & & 40 & 40 \\
\hline 62V1 Frh. Isbl. & 1 & & 36 & 37 \\
\hline 63V1 Færingehavn & $1 ?$ & & 5 & 6 \\
\hline 65V1 Sukkertoppen & 10 & & 2 & 12 \\
\hline $65 \mathrm{~V} 2$ Majorqaq & 7 & & 5 & 12 \\
\hline 66V1 Holsteinsborg & 37 & 24 & 5 & 103 \\
\hline $66 \mathrm{~V} 2$ Sdr. Strf. $\varnothing$ & 115 & & 11 & 128 \\
\hline 67V1 Ndr. Strf. V & 5 & 6 & & 11 \\
\hline 69V2 Jakobshavn & & 1 & 56 & 57 \\
\hline 71V1 Svartenhuk H. & 4 & 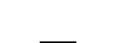 & 2 & 6 \\
\hline Total & 206 & 31 & 218 & 494 \\
\hline
\end{tabular}

KMS: Kort- og Matrikelstyrelsen (formerly Geodetic Institute).

The total number of localities on a map sheet is in some cases larger than the sum of kimberlites, lamproites and ultramafic lamprophyres, because for some localities the rock cannot be properly identified.

The name 'ultramafic lamprophyre' is used sensu lato and encompasses a rather large variety of rock types.

On the map sheets not listed there are no registered localities. For western Greenland these comprise $59 \mathrm{~V} 1,61 \mathrm{~V} 2,63 \mathrm{~V} 2,64 \mathrm{~V} 1,64 \mathrm{~V} 2$, $67 \mathrm{~V} 2,68 \mathrm{~V} 1,68 \mathrm{~V} 2,69 \mathrm{~V} 1,70 \mathrm{~V} 1,70 \mathrm{~V} 2,71 \mathrm{~V} 2$ and all sheets north of $73^{\circ} \mathrm{N}$.

of mid-Proterozoic age occurs in the Jakobshavn region (L. Skjernaa, unpublished data; map sheet $69 \mathrm{~V} 2$ ); its geochemistry seems akin to the diamondiferous lamproites of Bergman (1987).

\section{Ultramafic lamprophyres}

Ultramafic lamprophyres occur in a number of dyke swarms. One swarm in the Jakobshavn region (map sheet $69 \mathrm{~V} 2$ ) is mid-Proterozoic, $c$. 1650-1750 million years old (Marker \& Knudsen, 1989; unpublished data). A number of occurrences in South Greenland formed part of the widespread Gardar igneous activity 1100 1300 million years ago (e.g. Upton \& Emeleus, 1987; map sheet $60 \mathrm{~V} 1,60 \mathrm{~V} 2,61 \mathrm{~V} 1,61 \mathrm{~V} 3$ ). At least three, and probably four, swarms were emplaced into the Archaean craton during the Mesozoic period when rifting and crustal thinning in the Davis Strait took place in the first phase of the prolonged continental break-up process. These swarms occur south of Frederikshåb (map sheet 61V1; Walton \& Arnold, 1970), around Frederikshåb Isblink (map sheet 62V1; Hansen, 1979, 1980,
1981, 1984), and in the Sukkertoppen region in association with the Qaqarssuk carbonatite complex (Larsen et al., 1983; unpublished data). A few dyke occurrences near Færingehavn (map sheet 63V1), of which one is a possible kimberlite, are also Mesozoic.

Ultramafic lamprophyres only contain diamonds in very rare instances; these melts are usually generated at lower pressure than kimberlites, well outside the stability field of diamond.

\section{Conclusions}

A computer-based registration system for potentially diamondiferous rocks in Greenland has been established at GGU, thereby providing interested parties with easy access to the existing, very heterogeneous body of information about occurrences of such rocks.

The few microdiamonds yielded by the kimberlites at the northern and southern margins of the Archaean craton show that the lithosphere beneath Greenland is capable of yielding diamondiferous rocks, provided that their origin is sufficiently deep. The best prospect for future investigations is considered to be the kimberlites from the Sukkertoppen region, in the central part of the Archaean block. However, whereas dykes are known, no pipes have been found in this area (Lappalainen, 1972). Another prospect is the lamproite in the Disko Bugt area; the known pipe is very small, but there may be other, as yet undiscovered occurrences. The swarm of ultramafic lamprophyres in the same region, and of the same age, may perhaps have some diamond potential, because the rocks show affinities to diamondiferous olivine lamproites.

\section{References}

Andrews, J. R. \& Emeleus, C. H. 1971: Preliminary account of kimberlite intrusions from the Frederikshăb district, SouthWest Greenland. Rapp. Grønlands geol. Unders. 31, 26 pp. Andrews, J. R. \& Emeleus, C. H. 1975: Structural aspects of kimberlite dyke and sheet intrusion in south-west Greenland. In Ahrens, L. H., Dawson, J. B., Duncan, A. R. \& Erlank, A. J. (ed.) Physics and chemistry of the Earth 9, 43-50.

Andrews, J. R. \& Emeleus, C. H. 1976: Kimberlites of West Greenland. In Escher, A. \& Watt, W. S. (ed.) Geology of Greenland, 574-581. Copenhagen: Geological Survey of Greenland.

Bergman, S. C. 1987: Lamproites and other potassium-rich igneous rocks: a review of their occurrence, mineralogy and geochemistry. In Fitton, J. G. \& Upton, B. G. J. (ed.) Alkaline igneous rocks. Spec. Publ. geol. Soc. Lond. 30, 103-190.

Brunet, J. 1974: Concessions granted to Charter Consolidated 
Limited in the areas of Holsteinsborg and Frederikshåb in western Greenland. Report on exploration. Charter Consolidated Ltd. intern. rep., $12 \mathrm{pp}$.

Brunet, J. 1976: Report on the investigation of the Holsteinsborg concession, western Greenland. Charter Consolidated Ltd. intern. rep., $25 \mathrm{pp}$.

Geisler, R. A. 1972: Investigations on the Renzy Mines Limited Frederikshåb concession, Greenland, to June 15, 1972. Renzy Mines Ltd. intern. rep., 6 pp.

Goff, S. P. 1973: The mineralogy and geochemistry of a kimberlite dyke from Søndre Isortoq fjord, South-West Greenland. Unpublished M.Ph. thesis, Leicester Univ.

Hamilton, R. \& Rock, N. M. S. 1990: Geochemistry, mineralogy and petrology of a new find of ultramafic lamprophyres from Bulljah Pool, Nabberu Basin, Yilgarn Craton, Western Australia. Lithos 24, 275-290.

Hansen, K. 1979: Lamprofyrgange fra Frederikshåbs Isblink, syd vest Grønland. Unpublished thesis, Univ. Copenhagen, 83 pp.

Hansen, K. 1980: Lamprophyres and carbonatitic lamprophyres related to rifting in the Labrador Sea. Lithos 13, 145-152.

Hansen, K. 1981: Systematic Sr-isotopic variation in alkaline rocks from West Greenland. Lithos 14, 183-188.

Hansen, K. 1984: Rare earth abundances in Mesozoic undersaturated alkaline rocks from West Greenland. Lithos 17, $77-85$.

Lappalainen, P. 1972: Magnetic surveys of kimberlites and electromagnetic surveys in Fox Valley and Ulamertoq. Kryolitselskabet Øresund A/S intern. rep. 127, 2 pp. + app.

Larsen, L. M. 1980: Lamprophyric and kimberlitic dykes associated with the Sarfartôq carbonatite complex, southern West Greenland. Rapp. Grønlands geol. Unders. 100, 65-69.

Larsen, L. M., Rex, D. C. \& Secher, K. 1983: The age of carbonatites, kimberlites and lamprophyres from southern West Greenland: recurrent alkaline magmatism during 2500 million years. Lithos 16, 215-221.

Marker, M. \& Knudsen, C. 1989: Middle Proterozoic ultra- mafic lamprophyre dykes in the Archaean of the Atâ area, central West Greenland. Rapp. Grønlands geol. Unders. 145, 23-28.

Rock, N. M. S. 1986: The nature and origin of ultramafic lamprophyres: alnöites and related rocks. J. Petrology 27, 155-196.

Scott, B. H. 1977: Petrogenesis of kimberlites and associated potassic lamprophyres from central West Greenland. Unpublished Ph.D. thesis, Univ. Edinburgh, 133 pp.

Scott, B. H. 1979: Petrogenesis of kimberlites and associated potassic lamprophyres from central west Greenland. In Boyd, F. R. \& Meyer, H. O. A. (ed.) Kimberlites, diatremes, and diamonds: their geology, petrology, and geochemistry. Proc. 2nd int. kimberlite conf. 1, 190-205. Washington: Amer. geophys. Un.

Scott, B. H. 1981: Kimberlite and lamproite dykes from Holsteinsborg, West Greenland. Meddr Grønland Geosci. 4, 24 pp.

Scott-Smith, B. H. \& Skinner, E. M. W. 1984: Diamondiferous lamproites. J. Geology 92, 433-438.

Smith, B. H. S. 1981: Report on the laboratory investigation of rock samples from western Greenland. Charter Consolidated Ltd. intern. rep., 14 pp.

Thy, P., Stecher, O. \& Korstgård, J. A. 1987: Mineral chemistry and crystallization sequences in kimberlite and lamproite dikes from the Sisimiut area, central West Greenland. Lithos 20, 391-417.

Upton, B. G. J. \& Emeleus, C. H. 1987: Mid-Proterozoic alkaline magmatism in southern Greenland: the Gardar province. In Fitton, J. G. \& Upton, B. G. J. (ed.) Alkaline igneous rocks. Spec. Publ. geol. Soc. Lond. 30, 449-471.

Walton, B. J. \& Arnold, A. R. 1970: Plutonic nodules in lamprophyric carbonatite dykes near Frederikshåb, SouthWest Greenland. Bull. Grønlands geol. Unders. 91, 26 pp. (also Meddr Grønland 190(5)).

L. M. L., Geological Survey of Greenland, Copenhagen. 